Production

ENGINEERING ARCHIVES
2015,Vol. 7, No 2, pp 49-52

ISSN 2353-5156

ISSN 2353-7779 (print version)

(online version)

Article history: $\quad$ Received: 16.12.2014

Accepted: 10.03.2015

Online: 30.04 .2015

Available online on: http://www.qpij.pl

Exist since $4^{\text {rd }}$ quarter 2013

\title{
Traverse Grinding of X6CrNiMoTi Steel and its Final Surface Quality for Giving Cutting Conditions
}

\author{
Nataša Náprstková ${ }^{1}$, Martin Novák ${ }^{2}$, Júlia Hricová ${ }^{3}$ \\ ${ }^{1}$ Faculty of Production Technology and Management, Jan Evangelista Purkyně University in Ústí nad Labem, Pasteurova 1, 40096 Ústí nad \\ Labem, Czech Republic, +420 475285 513, naprstkova@fvtm.ujep.cz \\ ${ }^{2}$ Faculty of Production Technology and Management, Jan Evangelista Purkyně University in Ústí nad Labem, Pasteurova 1, 40096 Ústí nad \\ Labem, Czech Republic, +420 475285 536, novak@fvtm.ujep.cz \\ 3Faculty of Environmental and Manufacturing Technology, Technical University of Zvolen, Študentská 26, 96053 Zvolen, Slovak Republic, \\ +421 455206 842, julia.hricova@tuzvo.sk
}

\begin{abstract}
Machining of stainless steels is often an important used technology. Products made from these materials are often used in mechanical engineering and the quality of workpiece surface roughness after machining respective grinding is one of the important parameters that illustrates the quality of the machining process. This paper deals with the influence of cutting conditions when grinding steel X6CrNiMoTi (EN ISO) on the machined quality surface (roughness, circularity). Grinding of samples was carried out by feed grinding and the measured values were analyzed. On the machined samples parameters were all monitored and measured in the laboratory of precision measurements at the Faculty of Production Technology and Management of Jan Evangelista Purkyně University in Ústí nad Labem and the devices Hommel tester T1000 and Hommel tester Form 1000 were used. Measuring was done according to ČSN EN ISO 4287.
\end{abstract}

Key words - grinding, surface quality, stainless steel, cutting conditions

\section{Introduction}

This paper deals with an experiment that was conducted at FPTM JEPU. It was grinded under certain cutting stainless steel and the achieved roughness of machined surfaces has been evaluated.

Grinding technology belongs with the honing, lapping and superfinishing to abrasive finishing methods. In terms of technological outputs of this technology, there are particularly important parameters to achieve precision machined surfaces. (MARINESCU, I. 2007).

Stainless steels belong to a group of difficult to cut materials, mainly due to their tendency to harden due to cold, low thermal conductivity and good toughness. (NovÁK, M. 2011A, KOCMAN, K. 2012).

Surface roughness is a parameter describing the qualitative character of the machined surface and it is one of the many parameters that the technologist must take into account when choosing a machine tool and the used cutting tool and when determining cutting conditions. (VALÍČEK, J. 2008, MÁDL, J. 2008, JERSÁK, J. 2012).

Currently in the practice, the most commonly used parameter is $\mathrm{Ra}$ - arithmetical average deviation of the profile under consideration, further the greatest height of the profile $\mathrm{Rz}$ and the total height of the profile Rt. 
(KALINCOVÁ, D. 2010, NovÁK, M, 2012, MÁDL, J. 2012). Another important parameter of the machined surface is the material share curve (material ratio), which tells us how a large proportion of the material profile components attribute to the profile core and what proportion the projections and recess are. This curve is especially important when dealing with the issue of the functional surface (loading, wear, tribology, etc.). The last analyzed parameter of the experiment was geometric accuracy, specifically roundness irregularity of the machining surface (in according to standard ČSN EN ISO 4291. (NOVÁK, M. 2011b, ROKYTA, L. 2012).

Analysis of roundness, as one of the components of the geometric accuracy has for the manufacturing process and especially for the operation of the components, as important a meaning as the surface roughness. (DUGIN, A. 2013, STANČEKOVÁ, D. 2008).

\section{Experiment}

Research of the grinding impact on the machined surface was realized specifically for the material X6CrNiMoTi, chrome-nickel austenitic steel marked 1.4571 according to EN 10088-1. This steel has a tensile strength Rm 520-690 MPa.

Machining of the test sample was realized on a grinding machine BU-16. Machined surfaces were acquired by feed grinding. When machining the test sample, cutting fluid Emulkat Al $4000 \mathrm{CZ}$ was used. Used cutting fluid does into contain chlorine, which makes it environmentally friendly and disposal. Cutting conditions for individual test samples are presented in Table 1.

Table 1. Cutting conditions of experiment

\begin{tabular}{|c|c|c|c|c|}
\hline $\begin{array}{l}\text { Method } \\
\text { of } \\
\text { Grind- } \\
\text { ing }\end{array}$ & $\begin{array}{l}\text { Grindin } \\
\text { g Wheel }\end{array}$ & $\begin{array}{l}\text { Cuttin } \\
\text { g } \\
\text { Speed } \\
{\left[\mathrm{m} \cdot \mathrm{s}^{-1}\right]}\end{array}$ & $\begin{array}{c}\text { Speed of } \\
\text { Workpiec } \\
\text { e [m.min } \\
\left.{ }_{1}\right]\end{array}$ & $\begin{array}{c}\text { Feed } \\
\text { Speed } \\
\mathbf{v}_{\mathbf{p}}, \\
{[\mathrm{m} . \mathrm{min}} \\
\left.{ }^{-1}\right]\end{array}$ \\
\hline \multirow{2}{*}{ 总 } & \multirow{2}{*}{ 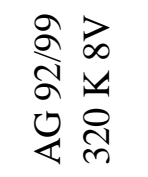 } & 35 & 15 & 0.02 \\
\hline & & 40 & 15 & 0.02 \\
\hline
\end{tabular}

When machining the test sample, grinding wheel designated AG 92/99 $320 \mathrm{~K} \mathrm{8V}$ was used. The grinding wheel AG 92/99 $320 \mathrm{~K} 8 \mathrm{~V}$ is formed from abrasive with 50\% SG grain. Abrasive grains are particularly fine as it is a soft wheel. The wheel structure is porous and the wheel binder is ceramic. (JUSKO, O. 2010)

\section{Roughness analyses}

On the machined samples parameters were monitored and in the laboratory of precision measurements of the FPTM were taken. Roughness parameters and surface profile were measured using a Hommel tester T1000 device according to EN ISO 4287. (OsicKA, K. 2009, KALINCOVA, D. 2010)

To evaluate the experiment roughness parameters $\mathrm{Ra}, \mathrm{Rz}$, and material ratio profile curve $\mathrm{Rmr} 0,1$ (50.0\%) were used, obtained from measuring protocols, from which the arithmetic mean was calculated. (NovÁK, M, 2014, MÁDL, J. 2012)

The measurements were summarized in graphs and analyzed. In Fig. 1 is a graph which shows the effect of cutting speed on the values of $\mathrm{Ra}$ in the longitudinal method of grinding (creep feed grinding). The graph shows that after increasing the cutting speed from 35 $\mathrm{m} . \mathrm{s}^{-1}$ to $40 \mathrm{~m} . \mathrm{s}^{-1}$ at the feed $0.02 \mathrm{~m} . \mathrm{min}^{-1}$ the roughness Ra decreased from 0.36 micron to 0.12 micron, which means that an increase in cutting speed was achieved by improving surface roughness Ra about $66 \%$.

In the Figure 2 is a graph which represents the effect of the cutting speed at the greatest height of the profile Rz. From the graph it can be seen that increasing the cutting speed from $35 \mathrm{~m} . \mathrm{s}^{-1}$ to $40 \mathrm{~m} . \mathrm{s}^{-1}$ at feed rate $0.02 \mathrm{~m} \cdot \mathrm{min}^{-1}$ reduced the value $\mathrm{Rz}$ about $47 \%$.

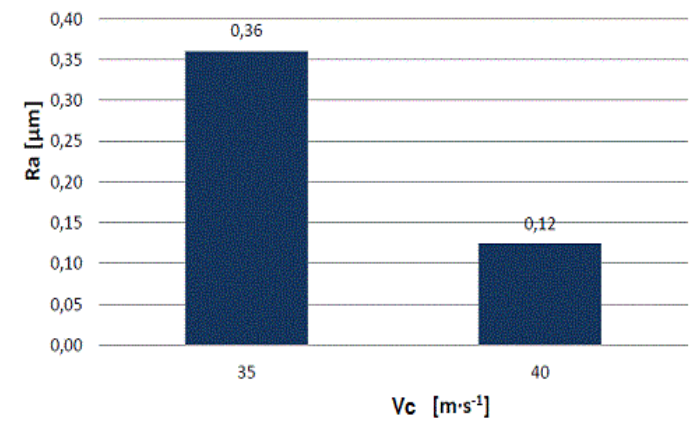

Fig. 1. The values of average roughness $\mathrm{Ra}$ of the surface after grinding. 
On measured samples surface profile and material ratio were also measured. It was possible to observe the change of the surface profile and material proportion after increasing the cutting speed from $35 \mathrm{~m} . \mathrm{s}^{-1}$ to $40 \mathrm{~m} \cdot \mathrm{s}^{-1}$ at feed rate $0.02 \mathrm{~m} \cdot \mathrm{min}^{-1}$. In Figure 3 is an example of the material ratio curve of the grinded sample.

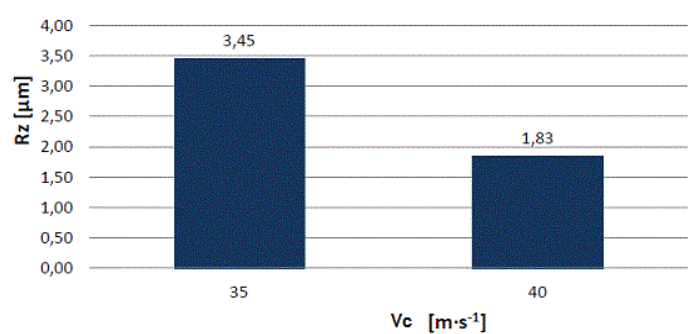

Fig. 2. The values of average roughness $\mathrm{Rz}$ of the surface after grinding.

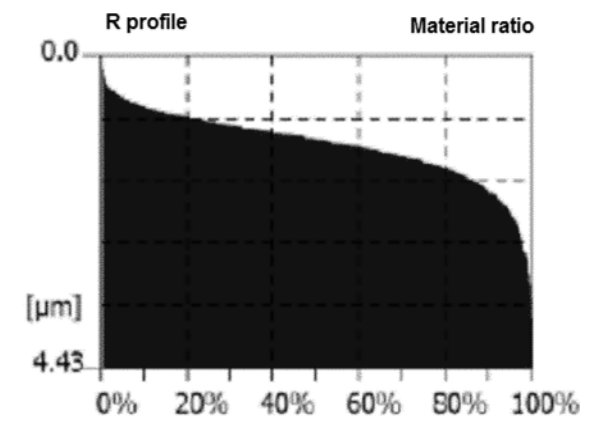

Fig. 3. Material ratio curve for $v_{c}=35 \mathrm{~m} \cdot \mathrm{s}^{-1}$ and $v_{p}=0,02 \mathrm{~m} \cdot \mathrm{min}^{-1}$.

After analyzing the measured values, it was found that during the increase of cutting speed, all observed values were reduced. From the course of the surface profile it can be seen that the mean distance between grooves is reduced about $43 \%$, material ratio Rmr01 (50.0\%) about $57 \%$, and the greatest height profile Rt decreased about $42 \%$.

\section{Roundness analyses}

Measurement of roundness deviation was also conducted in the laboratory of precision measuring of the Faculty of Production Technology and Management. For measurement the measuring device Hommel Tester Form 1000 was used. After processing the measured values the arithmetic mean was calculated (OsicKA, K. 2009, KALINCOVA, D. 2010).
In Figure 5 is a graph of this deviation, where it is possible to monitor the effect of cutting speed on the deviation from roundness for the longitudinal method of grinding. The graph shows that with the increase of cutting speed from $35 \mathrm{~m} . \mathrm{s}^{-1}$ to $40 \mathrm{~m} . \mathrm{s}^{-1}$ at feed rate 0.02 $\mathrm{m} . \mathrm{min}^{-1}$ the roundness deviation decreased from 0.84 micron to 0.82 micron, which means about $2 \%$.

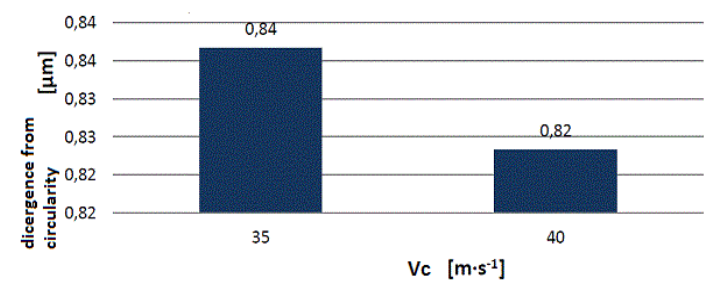

Fig. 5. Deviation from roundness in depending on the cutting conditions.

\section{Conclusion}

In the experiment, samples were machined from the material $\mathrm{X} 6 \mathrm{CrNiMoTi}$, which is stainless steel. Samples from this material were machined with longitudinal grinding by the given cutting conditions (see Table 1). On machined surfaces, surface roughness Ra, $\mathrm{Rz}$, were measured and analysed and then the surface profile and material share and deviation from roundness.

After considering all the received parameters, surface roughness, surface profile, material ratio and deviations from roundness, it is possible to conclude that an increase of cutting speed during creep feed grinding positively affected all the studied parameters. With the increase of cutting speed the size of primary plastic deformation is reduced and a reduction of chips stamping. This may be caused, for example, by reducing the chip thickness subscribed to one grain of the grinding wheel, but also increasing the heat in the cutting zone.

It was therefore evaluated that the effect of cutting speed on surface quality was obtained by grinding longitudinal method. It was found that an increase in cutting speed reduces all observed values, namely the surface roughness, the surface profile, material ratio and deviations from roundness.

When comparing all measured parameters on surface quality it is possible to suggest that with grinding stainless steel $\mathrm{X} 6 \mathrm{CrNiMoTi}$ and increased cutting speed, there was always an average for positive change of the quality of the ground surface. 


\section{Acknowledgement}

Above mentioned results were created by means of the project in J. E. Purkyně University in Usti nad Labem "Materials and Human Resources for Enviroment". CZ.1.07/2.3.00/30.0028
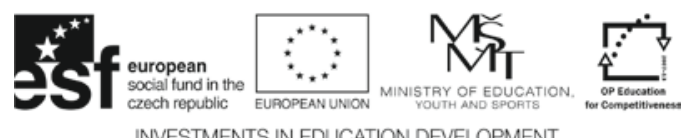

INVESTMENTS IN EDUCATION DEVELOPMENT

\section{References}

1. Dugin, A., Popov, A. 2013 Increasing the accuracy of the effect of processing materil and cutting tool wear on the ploughingforce values. In Manufacturing Technology, Vol 13, No.2, pp.169-173, ISSN 12132489.

2. JERSÁK, J. 2012 Vliv dynamického vyvážení brousicího kotouče na drsnost povrchu obrobených součástí (Effect of dynamic balancing of the grinding wheel on the surface roughness of machined components). In Strojírenská technologie (In Production Technology), Vol.17, No.1,2, p.27-33, ISSN 1211-4162.

3. JUSKO, O. 2010 Vývoj a inovace brousicich nástrojů (Development and innovation of grinding tools) In Strojírenská technologie (In Production Technology), Vol.15, No.1, p. 17-22, ISSN 1211-4162.

4. KALINCOVÁ, D. 2010 Skušanie mechanických vlastností materiálov - prehlad meracich metod a zariadeni (Testing of mechanical properties of materials overview of measuring methods and devices). KEGA 3/6370/08., TU vo Zvolene, Zvolen.,. p.13-26.

5. KoCMAN, K. 2012 Optimalizace dokončovacich operaci výrobnich procesu (Optimizing of finishing operations of manufacturing processes). In Strojírenská technologie (In Production Technology), Vol.17, No.3, p.164-169, ISSN 1211-4162.

6. MÁDL. J., HOLEŠOVSKÝ, F. 2008 Integrita obrobených povrchů z hlediska funkčnich vlastností (The integrity of the machined surfaces in terms of functional properties). Ústí nad Labem, FVTM UJEP, 230 p.

7. MÁDL, J. 2012 Surface Properties in Precise and Hard Machining. In Manufacturing Technology, Vol.12, No.13,. p.158-166, ISSN 1213-2489.

8. MARINESCU, I., D., et all. 2007 Handbook of Machining with Grinding wheels, Boca Raton, CRC Press,. 592 p.
9. NovÁK, M. 2011 Studium jakosti brouseneho povrchu kalenych oceli, cast I. - drsnost povrchu (Study of the ground surface quality hardened steels, Part I. - surface roughness, In Strojírenská technologie (In Production Technology), Vol.16, No.6,. p.26-33, ISSN 1211-4162.

10. NovÁK, M. 2012 Surface with high precision of roughness after grinding. Manufacturing Technology, Vol.12, No.12,. p.66-70, ISSN 1213-2489.

11. NovÁK, M. 2014 Grinding of stainless steel XCrNiMoTi and its final rooudness. Production Engineering Archives, Vol.5, No.4. PC, Cztestochowa, p. 18-21. ISSN 2553-5156.

12. OSIČKA, K. 2009 Prüměrná aritmetická úchylka drsnosti povrchu - statistické vyhodnoceni plochy. In Strojírenská technologie (In Production Technology), Vol.14, No.1, p.30-3, ISSN 1211-4162.

13. RокYTA, L., LuKovics, I. 2012 Výzkum vlivu poměrů brusiv na jakost povrchu pri broušeni. (Research of the abrasives ratio influence on the surface quality when grinding). In Strojírenská technologie (In Production Technology),. Vol.17, No.1,2,. p. 93-95, ISSN 12114162.

14. STANČEKOVÁ, D., ŠTEKLÁČ, A., CZÁN, A., ĎURECH, L., MLYNÁR, M. 2008 New Information about Dressing of Grinding Wheels. MITECH '08, 26.-27. 6. 2008, Praha, s. 202 - 207 ISBN 978 - 80 - 213 - 1792 - 5.

15. VAlíček, J., Rusnák, J., MÜller, M., Hrabě, P., KADNAR, M., HLOCH, S., KuŠnerovÁ, M. 2008 Geometrické aspekty drsnosti povrchu klasických a netradičnich technologií (Geometrical aspects of surface roughness of classic and innovative technologies). In Jemná mechanika a optika (In Precision Mechanics and Optics), Vol.53, No.9, p. 249-253. 